УАК 657

\title{
М. М. Шигун
}

доктор економічних наук, професор, завідувач кафедри обліку і оподаткування ДВНЗ “Київський національний економічний університет імені Вадима Гетьмана", Київ, Україна, shygun@ukr.net ORCID ID: https://orcid.org/0000-0003-1660-9534

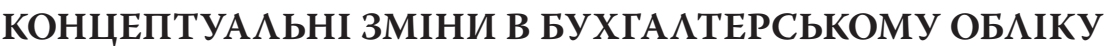 ПІА ВПАИВОМ СТА ООГО РОЗВИТКУ БІЗНЕСУ}

Анотація. Система бухгалтерського обліку як основа прийняття економічних рішень не може залишатись осторонь глобальних трансформацій та повинна гнучко реагувати на нові інформаційні потреби внутрішніх і зовнішніх користувачів та аАаптуватися Ао них. У статті розкрито характер впливу окремих цілей сталого розвитку на зміну ролі бухгалтерського обліку в процесах управ іння стійкістю бізнесу. Виявлено суперечності та невирішені питання стосовно окреслених цінностей, цілепокмадання й бачення глобальних і міжнародних організацій у частині піАходів Ао піАготовки звітної інформації з розкриттям показників сталості ААя потреб стейкхолдерів. Наведено перелік новацій у обліковій практиці, що забезпечать підготовку звітності нових форматів Аля цілей сталого розвитку. Увагу зосереАжено на необхіАності докорінної зміни мислення вцасників бізнесу, менеАжерів і всіх заАіяних фахівців, вкцючаючи бухгалтерів компаній, та його орієнтації на сталий розвиток. Обгрунтовано потребу у створенні в організаціях спеціацізованих піАрозАілів на базі бухгалтерської служби Аля піАготовки звітності інтегрованого формату, фахівці яких мають залучатися Ао процесів прийняття рішень щодо сталого розвитку бізнесу.

Кмючові слова: концепція сталого розвитку, глобальні цілі, звіт зі сталого розвитку, інтегрована звітність, звіт керівництва, глобальні принципи управ інсського обміку, стратегічний управ іінський облік.

Рис. 2. Міт. 24.

\section{Mariya Shygun}

Dr. Sc. (Economics), Professor, SHEE “Kyiv National Economic University named after Vadym Hetman", Kyiv, Ukraine, shygun@ukr.net ORCID ID: https://orcid.org/0000-0003-1660-9534

\section{CONCEPTUAL CHANGES IN ACCOUNTING UNDER THE INFLUENCE OF SUSTAINABLE BUSINESS DEVELOPMENT}

Abstract. The article reveals the nature of the impact of sustainable development goals on changing the role of accounting in the management of sustainable business development. The existing contradictions and unresolved issues in established missions, goalsetting and visions of global and international organizations are revealed in the approaches to preparing Sustainability Reporting for stakeholders. Signs of over-regulation of the preparation of sustainability reporting are disclosed. Due to the fact that various reporting formats for public sustainability reporting are used by companies, such reporting becomes incomparable. It is impossible to identify the criteria for defining non-financial indicators in the Sustainability Reporting and integrated reporting, which increases the risk of data unreliability. In particular, the IIRC's conflict of objectives (follow-up to sustainable development VS the value creation of the organization) is shown. The $<\mathrm{IR}>$ Framework is focused on financial capital providers' needs and long-term value creation, whose goals are based on profitability principles and diverging from the global sustainable development goals. A list of innovations in accounting practice is provided to ensure

(c) Шигун М. М., 2019 
the preparation of reporting in new formats for sustainable development goals. The emphasis is on the need for radical change in mindsets of business owners, managers and all involved professionals, including accountants of companies, and their focus on sustainable development. The need to create a specialized department in companies for integrated reporting and participation in the management of sustainable business development is substantiated. The preparation of integrated reporting is recommended in the subsystem of strategic management accounting, focused on the information provision of the strategic management of the company. The author gives proposals on the directions of the accountant's professional development to process non-financial data, the enhancement of adult life-long education, continuous professional education, and the creation of open knowledge bases to ensure the possibility of self-education.

Keywords: sustainable development concept, global goals, sustainable development report, integrated reporting, management report, global management accounting principles, strategic management accounting.

JEL classification: M41.

\section{М. М. Шигун}

доктор экономических наук, профессор, заведующая кафедрой учета и налогообложения

ГВУз “Киевский национальный экономический университет имени Вадима Гетьмана", Киев, Украина

\section{КОНЦЕПТУА ЬНЫЕ ИЗМЕНЕНИЯ В БУХГААТЕРСКОМ УЧЕТЕ ПОА ВАИЯНИЕМ УСТОЙЧИВОГО РАЗВИТИЯ БИЗНЕСА}

Аннотация. Система бухгалтерского учета как основа принятия экономических решений не может оставаться в стороне от глобальных трансформаций и Аолжна гибко реагировать на новые информационные потребности внутренних и внешних пользователей и аАаптироваться к ним. В статье раскрыт характер влияния отАельных целей устойчивого развития на изменение роли бухгалтерского учета в процессах управления устойчивостью бизнеса. Выявлены противоречия и нерешенные вопросы относительно обозначенных ценностей, целеполагания и видения глобальных и межАународных организаций в части подходов к поАготовке отчетной информации с раскрытием показателей устойчивости Аля нужА стейкхолАеров. Приведен перечень новаций в учетной практике, которые обеспечат поАготовку отчетности новых форматов Аля целей устойчивого развития. Внимание сосредоточено на необходимости коренного изменения мышления владельцев бизнеса, менеджеров и всех задействованных специалистов, вкАючая бухгалтеров компаний, и его ориентации на устойчивое развитие. Обоснована потребность в создании в организациях специализированных подразделений на базе бухгалтерской службы Аля подготовки отчетности интегрированного формата, специалисты которых Аолжны привлекаться к процессам принятия решений по устойчивому развитию бизнеса.

Кмючевые слова: концепция устойчивого развития, глобальные цели, отчет по устойчивому развитию, интегрированная отчетность, отчет руковоАства, глоба ьные принципы управленческого учета, стратегический управленческий учет.

Концепція сталого розвитку набуває у XXI ст. всеохоплюючого характеру та трансформує свідомість АюАства, вносить істотні корективи Ао політик країн світу, видозмінює стратегію розвитку бізнесу, створює якісно нові піАхоАИ Ао системи піАготовки інформації щоАо Аія ьноості суб’єктів госпоАарювання. 
За словами Генерального секретаря ООН Пан Гі Муна, цілі розвитку тисячоліття $є$ основою Аля появи нових передових партнерств, пожвавлення громаАської Аумки, а також мають величезне значення Аля постановки й Аосягнення широкомасштабних завАань $[1$, с. 3]. ПодаАьший план Аій Ао 2030 року (резолюція Генеральної Асамблеї ООН віА 25 вересня 2015 р. [2]) зосереАжує увагу на необхіАності спі ьних зусиль усіх країн із метою спрямування колективних Аовгострокових Аій на формування стійкого, комфортного та рівноправного світу, зАатного інтегрувати економічні, соціальні й екологічні виміри сталого розвитку $[1, \mathrm{c.} 3]$.

Технічний прогрес і винайдення нових способів обробки даних, істотні зміни в глобальному суспі ььстві та його запитах створюють нові виклики в бухгалтерській професії й висувають інші вимоги до підготовки нових форматів звітної інформації для різних груп стейкхолдерів, вкАючаючи економічні, соціальні та екологічні параметри даних. Система бухгалтерського обліку не може залишатись осторонь глобальних трансформацій і повинна гнучко реагувати й адаптуватися Ао нових інформаційних потреб внутрішніх та зовнішніх користувачів. Разом із тим бухгалтерська практика в частині формування показників сталості бізнесу засвідчує наявність низки невирішених питань і суперечностей у чинних регулівних документах, що стосуються Аосягнення глобальних цілей сталого розвитку.

В межах цієї статті основним завданням $€$ визначення характеру впливу окремих цілей сталого розвитку на зміну ролі бухгалтерського обліку в процесах управ іння бізнесом та облікової практики Аля потреб звітування стейкхолдерам, а також виявлення суперечностей у окреслених цінностях, цілепокмаданні й баченні глобальних і міжнародних організацій у частині піАходів Ао піАготовки звітної інформації з розкриттям показників сталості.

СтейкхолАери відчувають високу залежність віА якості, повноти та своєчасності інформації, що $\epsilon$ основою А я прийняття рішень. Це засвідчує ве-

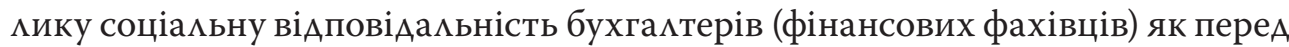
вмасниками й керівництвом суб'єктів господарювання, так і переА національним та глобальним суспільством, а також вимагає перегляду ролі бухгалтерів і міри їхньої участі в процесах управління бізнесом та його стійким розвитком. Окрім того, інформаційна обробка показників сталості потребує наявності у бухгалтерів (фінансових фахівців) спеціальних знань і вмінь Аля Аостовірної оцінки впливу параметрів Аіяльності економічного суб'єкта на навколишній світ.

ЦіАі сталого розвитку охоплюють різні сфери суспільного й економічного життя. СереА 17 цікей сталого розвитку та 169 завАань нового плану Аій, які набрали чинності 1 січня 2016 р., прямого посилання на завдання, що можуть реалізовуватися в системі бухгалтерського обліку, немає. ВоАночас облік, як система підготовки, інтерпретації та подання Ааних щодо економічної діяльності, виконує важливу роль у формуванні інформаційного піА-

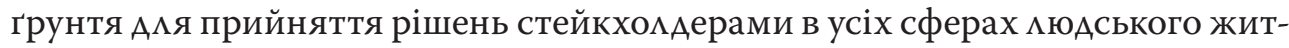


тя. Крім того, низка глобацьних цілей може Аосягатися безпосереАньо в освітній і професійній бухгалтерській Аія ьності. Зокрема, щодо вАосконамення промисловості, інновацій та інфраструктури, віАповіАального споживання й виробництва, якісної освіти, гендерної рівності, партнерства зараАи сталого розвитку. Розглянемо ті викцики, котрі виникають у бухгалтерській професії піА впливом зазначених цілей.

Глобальна ціль "Промисловість, інновації та інфраструктура" передбачає утворення стійкої соціальної та економічної інфраструктури, сприяння всеохоплюючій, сталій індустріалізації й запровадженню інновацій. Основний запит на виконання цієї цілі стосується власників бізнесу та керівництва суб'єктів господарювання, віА яких глобальне суспільство чекає на інвестування в інфраструктуру та здійснення інновацій. Таке інвестування виступає піАгрунтям економічного зростання й соціального розвитку.

ПіАвищення соціальної віАповідацьності бізнесу вимагає віА компаній акцентів на стратегії їх розвитку. Стратегічно орієнтоване управ $і$ іння, у свою чергу, зумовлює побудову чіткої системи піАготовки інформації про зовнішнє середовище, постійні зміни в якому потребують чіткого реагування й аАаптації бізнесу з метою підтримання його життєзАатності. Розроблена в Аругій половині ХХ ст. концепція стратегічного управління стала в 198090-х роках Аомінуючою в більшості світових компаній. ГАобальні цілі, сфор-

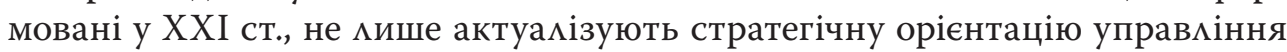
економічними суб'єктами, а й висувають нові вимоги до віАкритості бізнесу, Аоступності інформації про його Аія ььність і вплив на Аовколишній світ.

Відповідно, зазначена глобамьна ціль передбачає подання суб'єктами господарювання інформації щодо підвищення ефективності використання наявної енергії, прискорення переходу на поновлювані Ажерела енергії, запровадження нових, енергоефективних виробничих процесів, інформаційних і комунікаційних технологій та розширення доступу до них. Окрема глобацьна вимога стосується створення нових робочих місць, оптимацьного розв'язання наявних економічних і екологічних проблем тощо. Така інформація повинна відображатися в публічній звітності компаній.

Реалізація нових глобальних цілей не можмива без докорінної зміни мислення власників бізнесу, менеджерів та всіх задіяних фахівців, включаючи бухгалтерів компаній. Основними скмадовими мислення, орієнтованого на сталий розвиток, повинні стати:

- розуміння високої віАповіАацьності й підзвітності бізнесу переА суспільством;

- готовність Ао пубцічного розкриття інформації про реальний стан бізнесу та його Аинаміку;

- використання форматів звітності, що віАповіАають сучасним запитам стейкхомдерів;

- стратегічна орієнтація в управлінні бізнесом;

- урахування системи показників ризику та можиивих загроз у Аіяльності економічного суб’єкта, відображення їх у звітності; 
- постійний аналіз зовнішнього середовища та його впливу на Аинаміку бізнесу, оцінка впливу бізнесу на довколишній світ;

- готовність вживати заходи з віАновлення стану навколишнього сереАовища в разі його погіршення внаслідок Аія ьності економічного суб’єкта.

Концепція сталого розвитку зміщує вектор звітування компаній, що, у свою чергу, змінює роль професійної бухгалтерської спільноти та ставить бухгалтерський облік як окремий економічний інститут на службу глобальному суспільству. Прийнятий піАхіА до використання концепції сталого розвитку при піАготовці звітності компаній не тільки збільшує вагу саморегулювання процесу ведення обліку і скмадання звітності на їх рівні, а й піАкреслює роль бухгалтерів в управлінні суб'єктами господарювання як основних постачальників звітної інформації нового формату. ВіАповіАно, Аля повноцінного забезпечення виконання глобальної ці і “Промисловість, інновації та інфраструктура” необхідне якісне оновцення облікової методомогії, котра створить методичне підгрунтя Аля реалізації принципів сталого розвитку й збалансованого управління світовою економікою.

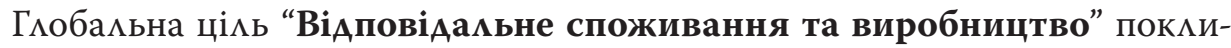
кана сприяти переходу Ао використання раціона ьних моделей споживання й виробництва. ВіАповіАацьність бізнесу та суспільства при цьому стосується якомога істотнішого зменшення впливу на екологію, що можииво завАяки впровадженню змін у виробництво та споживання ресурсів. Ця глобальна ціль спонукає бізнес вкцючати в публічну звітність показники управління природними ресурсами, скорочення обсягів віАходів (харчових і виробництва), застосованих методів утилізації токсичних відходів і забруднюючих речовин, проведених заходів з очищення вже забруднених воАних, земельних та повітряних ресурсів. Таким чином, суб'єкти господарювання мають фокусувати увагу стейкхолдерів на тій ролі, що її компанія виконує в процесі переходу до більш ресурсоефективної економіки.

3 огляду на зазначені глобальні цілі та інформаційні потреби стейкхолАерів, удосконалення бухгалтерської практики має грунтуватися на піАготовці відкритих звітних Ааних та їх розширенні, що Аасть можмивість суб'єктам господарювання відображати виконані заходи Аля створення стійкої інфраструктури, сприяння індустріалізації та запровадження інновацій, забезпечення переходу Ао раціональних моделей споживання й виробництва тощо. Зокрема, це передбачає піАготовку звітних Ааних за такими напрямами:

- зАійснені чи заплановані інвестиції в наукові дослідження та інновації;

- зниження ресурсозатратності технологій, переоснащення обладнання на більш раціона ьні моделі використання ресурсів, запровадження енергозберігаючих технологій;

- запровадження поновлюваних Ажерел енергії, енергоефективних технологій, піАвищення ефективності використання наявних енергоресурсів; 
- обсяги промислових віАходів, їх подальше перероблення, витрати на утилізацію токсичних відходів, забруднюючих речовин, проведені заходи 3 очищення воАних, земельних і повітряних ресурсів;

- створення нових робочих місць, гендерний розподіА зайнятості, піАвищення кваАіфікації та професійної майстерності в розрізі статевих груп працюючих, запровадження заходів Аля забезпечення гендерної рівності.

Втілення концепції сталого розвитку й розширення інформаційних вимог користувачів обумовлюють віАповіАне Аоповнення переліку звітних показників, дедалі більшу відкритість облікових даних та ставлять завдання зміни формату звітної інформації. У зв'язку з цим звітність компаній повинна містити різні типи показників - абсолютні (грошові, натуральні, трудові, комплексні) й відносні, кількісні та якісні. Формат такої звітності набуває інтегрованого характеру, оскі ььки вона вкцючає фінансові й нефінансові параметри Аіяльності суб'єктів господарювання.

Аля забезпечення користувачів звітними даними нового формату ГАобальною ініціативою зі звітності (GRI) розроблено пакет Стандартів звітності зі сталого розвитку (СтанАарти GRI) [3], котрі фактично стали першими й найпоширенішими ААя піАготовки звітності такого змісту та починаючи 3 1997 р. визнаються деАалі більшою кількістю організацій.

За даними останніх досліАжень KPMG, станом на кінець 2017 р. 93 \% найбільших із 250 світових корпорацій звітують про свою ефективність у сфері сталого розвитку $[4$, с. 9], при цьому на міжнародному рівні спостерігається тенденція збільшення кількості таких звітів. Разом із тим, незважаючи на очевиАний успіх запровадження стандартів GRI, залишається відкритим питання Аостовірності звітності, підготовменої за такими стандартами, критику яких можна побачити у статтях європейських експертів [5; 6].

ГАобальна ініціатива була широко підтримана $€ C$, результатом чого стало визначення вимог щодо відображення у звітності великих компаній і суб'єктів суспільного інтересу окремих нефінансових показників, а також піАготовки спеціалізованих звітів. Зокрема, Аирективою 2013/34/ЄС віА 26.06.2013 скасовано Аирективи 78/660/ЄЕС і 83/349/ЄЕС та переАбачено віАображення у Звіті керівництва фінансових і нефінансових кмючових показників ефективності, які стосуються конкретного бізнесу, вкАючаючи інформацію з питань навколишнього середовища й працівників, що забезпечує розуміння їх розвитку, Аіяльності й позиції [7, ст. 19]. СереАні та малі компанії можуть звільнятись урядами країн $\in C$ віА подання нефінансової інформації в таких звітах, окрім того, ма і компанії можуть взагалі звільнятися віА подання Звіту керівництва за умови надання віАповіАних приміток Ао фінансової звітності щодо придбання акцій власної емісії.

Окрему підтримку у сфері корпоративної соціальної відповідальності наАано шияхом запровадження Аирективою 2013/34/ЄС Звіту про платежі Ао бюАжетів країн виАобувних та Аісозаготівельних компаній [7, ст. 41-48], котрий повинен забезпечити доступ громадськості країн, що $€$ постачаАьниками природних ресурсів, Ао інформації про державні доходи віА продажу 
Аіцензій на ведення такої Аія ььності у співвіАношенні з обсягами втрат віАповіАних ресурсів. Таке звітування також покцикане перешкодити незаконному наАходженню корисних копалин і деревини на ринки Євросоюзу.

Зазначені зміни в європейському законодавстві свідчать про високу пріоритетність глобальних цілей сталого розвитку Аля Європарламенту й РаАи. Водночас чинні Аирективні вимоги не містять вичерпного поряАку піАготовки віАповіАної звітності та залишають багато віАкритих і Аискусійних питань. Прикладом детацьного аналізу та окреслення напрямів гармонізації вимог Аирективи 2013/34/ СС із українським законодавством є статті С. Я. Зубілевич [8] і А. В. Озеран [9]. Автори зупиняються на загальних питаннях імплементації вказаної директиви та її розбіжностях із вітчизняними й міжнародними нормативними вимогами.

Стандарти GRI та європейські Аирективи знаменують перехіА віА фінансової звітності компаній Ао інтегрованого формату звітів, який Аає можмивість публічно проілюструвати місію, стратегію, бізнес-моделі й ризики компаній, ефективність використання ними всіх виАів ресурсів (матеріацьних, фінансових, АюАських), рівень їхньої соціальної відповідальності та якість корпоративного управління. Звертаючи увагу на цей факт, варто зауважити, що саме розвиток концепції інтегрованої звітності, котра, на віАміну віА традиційного звітного формату, зАатна змалювати комплексну картину роботи компанії, на сьогодні $€$ центральною тенденцією у скцаАанні корпоративної звітності, орієнтованої на сучасні запити стейкхоцдерів та інноваційний характер облікових систем.

На підтримку концепції сталого розвитку у 2010 р. створено Міжнародну раду з інтегрованої звітності (The International Integrated Reporting Council IIRC), що визначає свою місію та бачення в Аосягненні компаніями світу більшої фінансової стабільності і сталого розвитку з використанням у ролі основних інструментів інтегрованої звітності та мислення [10]. У 2013 р. IIRC опублікувала Міжнародний стандарт 3 інтегрованої звітності (The International $<$ IR $>$ Framework, або $<I R>$ Framework), Ае закріплено фундаментальні концепції створення вартості, кцючові принципи піАготовки інтегрованої звітності та елементи їі змісту [11].

У своїй місії IIRC вбачає досягнення цілей сталого розвитку через скмаАання інтегрованого звіту, наголошуючи на цьому також у своїх дослідженнях і публікаціях. Зокрема, спеціалізоване дослідження К. А. ААамс 2017 р. присвячене розкриттю механізму ув'язки компаніями глобальних цілей сталого розвитку з процесом створення вартості [12, с. 5, 10-12]. Попри спроби автора констатувати та показати такий зв'язок схематично [12, с. 14], Аоказова база IIRC залишається неАостатньою й сумнівною. Конфлікт цілей цього міжнародного органу (сталий розвиток vs створення вартості організації) підсилюється тим, що в тексті <IR> Framework головна мета інтегрованого звіту - показати постача ьникам фінансового капіталу, як організація створює вартість протягом тривалого часу [11, с. 9]. При цьому варто врахувати, що цілі постачацьників фінансового капіта у, котрі базуються на 
принципах прибутковості, зазвичай розходяться із глобальними цілями збереження навколишнього сереАовища й природних ресурсів, віАповіАального споживання, віАновлення екології планети та ін.

Таким чином, наразі маємо доволі грунтовні розробки відповідних станАартів звітності, яка може відображати досягнення цікей сталого розвитку організаціями, втім, між цими стандартами $€$ Аосі не розв'язані суперечності, й кожна країна стоїть переА вибором формату звітності, котрий найкраще віАповіАатиме урядовій політиці в частині сталого розвитку цієї країни.

Світова практика скцадання та подання публічної звітності нефінансового або інтегрованого формату вже має власну історію. Так, із 1990 р. функціонує міжнародна онлайн-база даних нефінансової звітності "Corporate Register" [13]. ЗгіАно з Реєстром звітів із корпоративної віАповіАальності станом на 1 січня 2019 р., що ведеться Corporate Register із 1990 р., у світі 16403 компаніями піАготовлено 98497 звітів, котрі відображають показники екологічного, соціального й корпоративного управління, розкривають Аотримання концепції сталого розвитку та містять Аані нефінансового чи інтегрованого формату. Аинаміка розміщення звітів із корпоративної віАповіАальності за 2012-2016 рр. на інтернет-ресурсі Corporate Register, що враховує звіти зі 157 країн світу, відображена на рис. 1 [14].

Ha Corporate Register розміщено звіти як корпорацій, так і некорпоративних інституцій (урядових організацій, торговельних асоціацій, університетів тощо). Переважають нефінансові звіти, сереА яких екологічні, з корпоративної соціальної віАповіАальності, про сталий розвиток, інтегровані. За періоА 1990-2016 рр. на зазначеній платформі 14 українських компаній розмістили 74. звіти з можАивістю вільного доступу Ао них. За кількістю поданих звітів у реєстрі $\Lambda$ ілирують США із 10666 звітами віА 1735 організацій. Також високі показники Аемонструють Великобританія (9633 звіти віА 1421 організації),

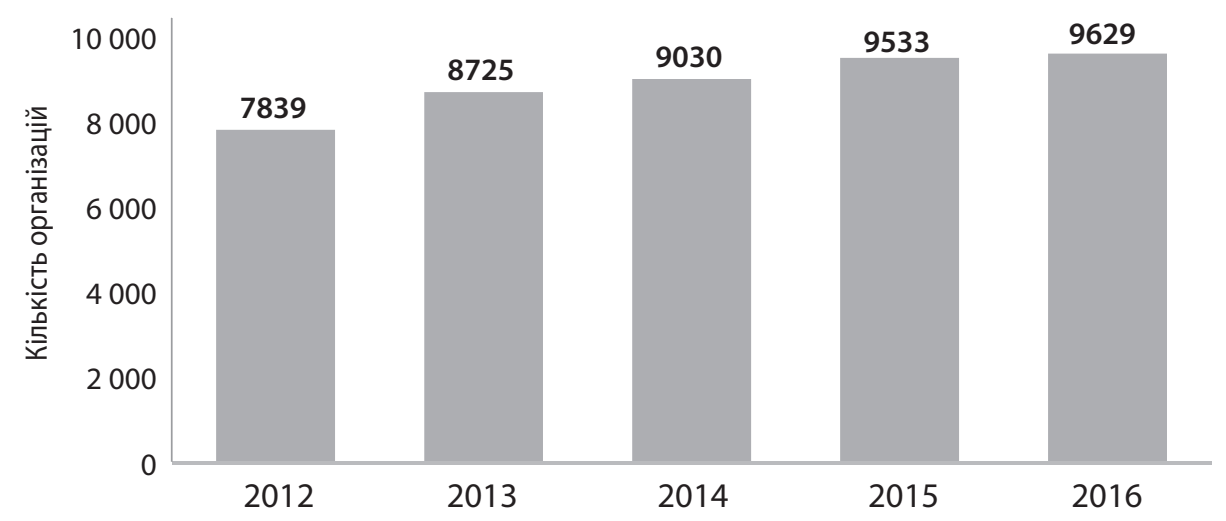

Р и с. 1. Аинаміка розміщення звітів з корпоративної відповідальності на інтернет-ресурсі Corporate Register 3a 2012-2016 pp.

Ажерело: Corporate Register. Tools. Live Charts. URL: http://www.corporateregister.com/livecharts/? chart $=1 \&$ cou $=$ All\&sec $=$ All\&sub=All\&our=All. 
Німеччина (6438 звітів віА 1126 організацій) та Японія (6580 звітів від 643 організацій). Corporate Register Аає можАивість проводити статистичну обробку розміщених звітів, проте застосування різних форматів звітності порушуе питання їх порівнянності й достовірності таких статистичних оцінок.

GRI теж має власну базу звітів зі сталого розвитку - GRI's Sustainability Disclosure Database [15], котра ведеться з 1996 р. Вона налічує 51318 звітів 13266 організацій, у т. ч. 31317 звітів за стандартами GRI, Аоступ до яких абсолютно вільний. Інтегровану звітність компаній світу можна побачити на сайті Міжнародної ради з інтегрованої звітності в спільному проекті з Black Sun Plc - Examples.integratedreporting.org [16]. У вільному доступі на цьому сайті 160 звітів за 2011-2018 рр., при цьому можливий пошук у розрізі керівних принципів, основних понять або елементів вмісту.

Враховуючи високу диверсифікацію типів звітності, її формат і наповнення, процес підготовки звітності компаній у XXI ст. не може повноцінно забезпечуватися тільки бухгалтерською скужбою. Широкі запити користувачів щодо інформаційних показників потребують залучення практично всіх піАрозАілів і служб до піАготовки віАповіАних Ааних. Окрема група фахівців бухгалтерської служби, або спеціально створений департамент зі звітності компанії (стратегічного обліку, сталого розвитку бізнесу) має узагальнювати підготовмену інформацію та приводити її до визначеного формату. Зокрема, підготовка інтегрованої звітності вимагає створення на суб'єктах господарювання підсистеми стратегічного управлінського обціку, орієнтованої на забезпечення стратегічного управ іння компанією.

Якісна підготовка інформації в підсистемі стратегічного управлінського обліку порушує питання наявності відповіАного методологічного забезпечення процесів обробки та зведення Ааних. Методи стратегічного управлінського обліку кардина ььно віАрізняються віА кАасичної облікової методології, грунтуються не на принципах подвійності, а переважно на аналітичних прийомах. У більшості наукових праць використовуються різні набори метоАів обліку Аля цілей стратегічного управління, при цьому, за словами авторів, ця методологія перебуває в стаАії розвитку та щільно переплітається 3 методами управ іння [17-19]. ІАеться, зокрема, про облік витрат за видами Аіяльності (activity-based costing - ABC), систему планування потреби в матеріалах (material resource planning - MRP), поставки точно в строк (Workflow GIT (“just in time”)), калькулювання стадій життевого цикму (lifecycle costing), розрахунок цільової собівартості (target costing), систему безперервного вдосконалення (kaizen costing), теорію обмежень (drum-buffer-rope scheduling - DBR Theory), концепцію канцюга цінностей (value chain concept - VCC), збалансовану систему показників в управлінні кмючовими бізнес-процесами (Balanced Scorecard - BSC), бюАжетування або еталонне оцінювання (benchmarking) та ін. [20, с. 155-157].

Наведені методи стратегічного управлінського обліку засвідчують їх принципову віАмінність за піАходами Ао збору інформації, ії обробки й узагальнення. Отже, облікова методологія у XXI ст. зазнає нових викликів, які 
стимулюють її до розширення й Аоповнення Аосі нетиповими анаАітичними методами та вимагають віА бухгалтерів (фінансових фахівців) Аоскона Аішого володіння математичними і статистичними процедурами обробки Ааних.

Поширення в економічно розвинутих країнах інформаційної піАсистеми стратегічного управ інського обліку Аістало Аогічне продовження в її станАартизації. Завдання розроблення таких стандартів узяв на себе Привілейований інститут управлінських бухгалтерів (СIMA), який у 2014 р. преАставив ГАобальні принципи управлінського обліку (ГПУО) [21]. У 2017 р. у Києві відбулася презентація ГПУО в офіційному перекладі українською мовою. Основним їх призначенням $є$ вивчення найкращих практик бухгацтерського обліку та формування універсального переліку принципів, Аотримання яких сприяє прийняттю скмаАних рішень, що забезпечують сталу цінність компанії. У структурі ГПУО преАставлені власне принципи управлінського обміку, умови їх застосування та роль в управлінні ефективністю компанії, порядок їх практичного використання [21].

При розкритті мети ГПУО наголошено на тому, що фахівці з управлінського обліку можуть пропонувати піАходи Ао організаційного управАіння, котрі сприятимуть розробленню й реалізації стратегії ефективної Аіяльності організації [21, с. 4]. На Аумку авторів, ГПУО можуть спонукати Ао визнання кАючової ролі управлінського обліку в організаціях та застосування його на найвищому рівні, а також забезпечити найкращу реалізацію потенціалу управлінського обліку Аля цікей ефективного управління економічними суб'єктами.

Зростання ролі фахівців з управлінського обліку піАтверАжується також Аослідженнями Асоціації міжнародних Аипломованих професійних бухгалтерів (AICPA), Ае наведено факти кардинальної зміни ролі фінансових фахівців (котрі об’єАнують бухгалтерів, управлінських бухгалтерів, фінансових аналітиків) віА роботи в ізоляції Ао Аіяльності в поєАнанні й тісній комунікації з іншими фахівцями [22, с. 3]. Експерти зауважують, що наразі очікування стосовно ролі фінансів істотно зміницися - тепер останні “вбуАовуються в бізнес" [23, с. 2].

Потреба в піАготовці стратегічної інформації дедалі більше обумовлює залучення бухгалтерів (фінансових фахівців) Ао процесів управління, веАення переговорів із контрагентами, налагодження комунікацій із кАієнтами, зАійснення впливу на прийняття рішень. При цьому віА них вимагається майстерне володіння технічними фаховими навичками, високий рівень аналітичних вмінь, глибоке розуміння бізнесу.

За оцінками експертів, практика управлінського обліку, що базується на ГПУО, зАатна забезпечити створення інтегрованої інформації, яка піАтримує інтегроване мислення та прийняття рішень із урахуванням фінансових і нефінансових Ааних у різних часових межах [24, с. 7]. Фахівці з управлін-

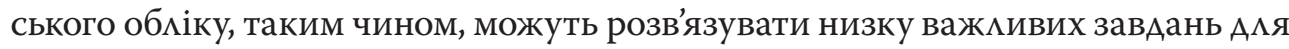
організацій, а саме: зменшення надміру даних, що надходять керівництву; врахування соціальних і екологічних зобов'язань організації при піАготовці фактичної й анахітичної управлінської інформації; Аоповнення фінансових 
звітних Ааних змістовним описовим анацізом та нефінансовими показниками, що Аолає орієнтованість звітності на минулі поАії й піАвищує ефективність стратегічного управАіння.

Такий насліАок поєАнання фінансових і нефінансових Ааних у стратегічному контексті позитивно оцінюється переважною більшістю керівників компаній. Зокрема, вони віАзначають результативніші іАентифікацію та управління ризиками (96 \%); швиАше прийняття бізнес-рішень (96 \%); ширші перспективи, більш Аовгостроковий погляд на ефективність Аіяльності компанії (96 \%); створення атмосфери довіри й упевненості зі стейкхолдерами (92 \%); зміцнення віАносин із інвесторами та креАиторами (88 \%) [24, с. 11]. Загалом ГПУО розгАяАаються як інструмент Аля Аосягнення успіху Аіяльності завАяки формуванню в підсистемі управлінського обліку об'єктивних Ааних і виважених суджень на основі віАповіАних принципів. Проведення фахівцями з управлінського обліку постійного аналізу ринкового й макроекономічного середовищ, Аинаміки економічних показників із урахуванням особливостей бізнес-моделі підприємства забезпечує високу стабільність успіху бізнесу.

Краще уявлення про розглянуті елементи глобальної системи нормативного регулювання нових форматів звітності організацій дає рис. 2. У межах схеми звертаємо увагу на наявні вимоги стандартів і Аиректив, що утворюють віАповіАні формати звітної інформації (звіт зі сталого розвитку, інтегрована звітність, звіт керівництва тощо), які обираються економічними суб'єктами Аля цілей звітування про сталий розвиток бізнесу переА стейкхолдерами. В окремій зоні зображено необхіАні зміни в системі піАготовки звітної інформації на рівні компанії з урахуванням потреби в інтеграції фінансових і нефінансових даних.

Узага ьнений погляА на місію та бачення глобальних і міжнародних організацій, чиї нормативні Аокументи розглянуті в цьому АосліАженні, свіАчить про наявність низки невирішених питань та суперечностей у обраних ними підходах щодо інформування стейкхолдерів, а саме:

- істотна зарегульованість системи піАготовки звітності, вкАючаючи показники сталого розвитку (стандарти GRI, <IR> Framework, Аирективи $\mathrm{CC,} \mathrm{ГПУО);}$

- різні цілепокладання, місія та бачення, закладені в систему звітування зі сталості;

- використання неоднакових форматів звітності (звітність зі сталого розвитку - повне розкриття показників сталості; інтегрована звітність спроба пов'язати фінансові цілі організацій із цілями сталого розвитку; Звіт керівництва й Звіт про платежі до бюАжетів країн видобувних та $\Lambda$ ісозаготівельних компаній - окремі групи показників сталого розвитку);

- Аовільний вибір звітного формату компаніями внаслідок скмаАності поєАнання піАхоАів різних організацій щодо публічного звітування зі стамості, що робить опубліковану звітність непорівнянною;

- необхідність вибору певного формату звітності Аля відображення показників сталого розвитку на рівні країн світу Аля їх внутрішнього нормативного врегулювання (Звіт зі сталого розвитку, інтегрована звітність, Звіт керівництва, 

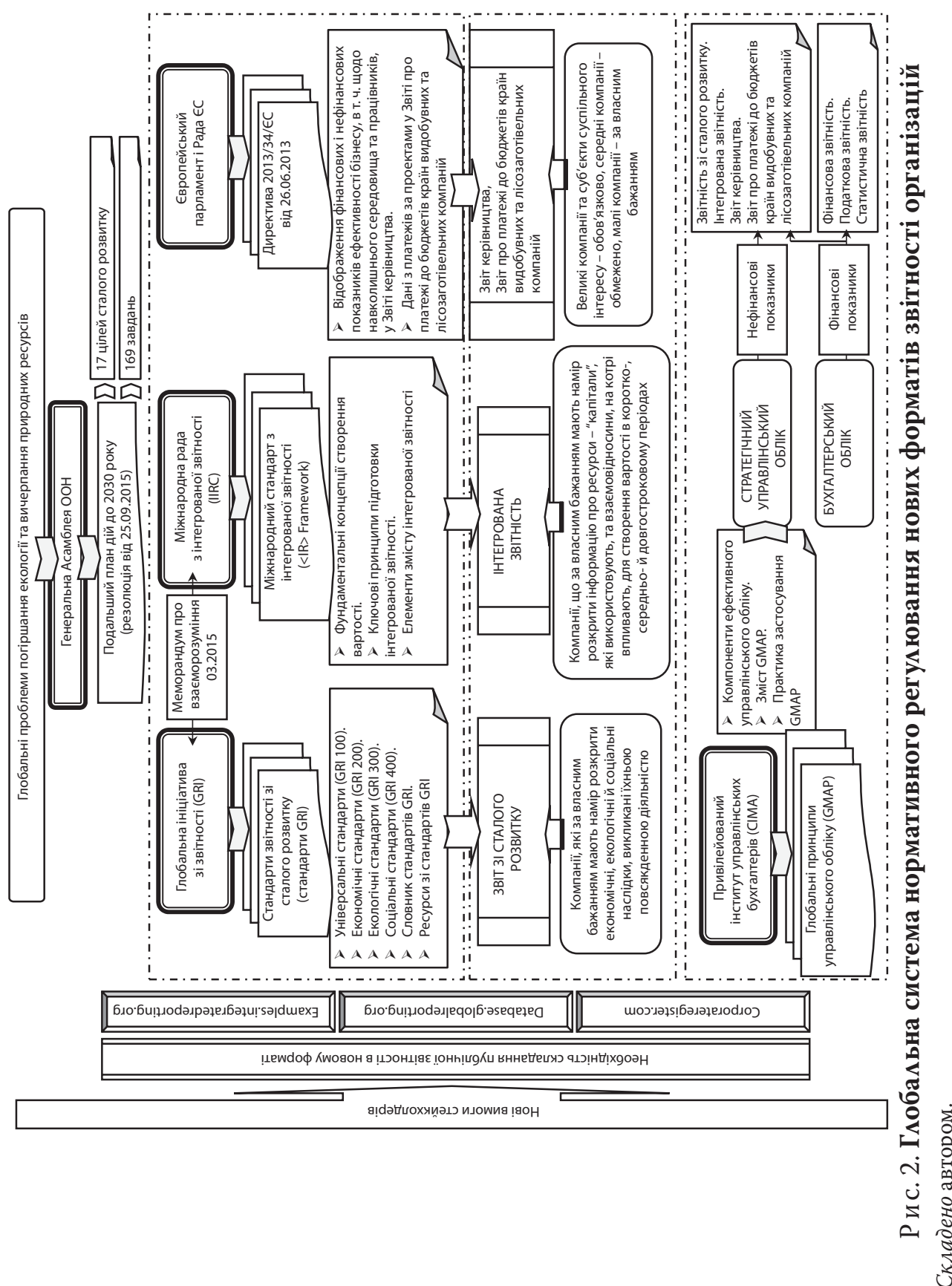
Звіт про управління, Звіт про платежі до бюджетів країн видобувних та Аісозаготівельних компаній, Звіт про платежі на користь держави піАприемств тощо);

- неможливість ідентифікації критеріїв, за якими визначено нефінансові показники у звітах зі сталого розвитку та інтегрованій звітності, що зумовАює ризик її неАостовірності;

- відсутність системи незалежного аудиторського контролю достовірності оприлюАнених нефінансових звітів (виняток становцять звіти великих компаній і суб'єктів суспі ььного інтересу, скмадені за вимогами директив $Є С$ );

- брак віАпрацьованої методологічної бази Аля визначення нефінансових показників, котра виходила б за межі кмасичних метоАів бухгалтерської обробки даних;

- недостатній рівень кваліфікації бухгалтерів (фінансових фахівців) А я опрацювання нефінансових даних математичними, статистичними, анацітичними методами, потреба в їх навчанні й піАвищенні кваліфікації;

- необхідність створення в організаціях спеціалізованого піАроздіку на базі бухгалтерської служби Аля піАготовки звітності нових форматів;

- потреба в перегляді ролі бухгалтерів та визначенні ступеня їх участі в управлінських процесах компаній із урахуванням нового формату інформаційної піАтримки прийняття рішень.

Наведені невирішені питання й суперечності у підходах та баченні глобальних і міжнародних організацій щодо підготовки інформації зі сталості бізнесу Аля стейкхолдерів окреслюють нові, перспективні напрями наукових АосліАжень.

Проблема недостатнього рівня кваліфікації бухгалтерів (фінансових фахівців) Аля опрацювання нефінансових даних повинна бути розв'язана в межах глобальної цімі "Якісна освіта", котра передбачає забезпечення всеохопАюючої і справеАливої якісної освіти, а також можливість навчання впродовж усього життя А я кожного, оскільки така освіта $\epsilon$ запорукою високого рівня соціального й економічного розвитку. У сфері професійної бухгалтерської Аіяльності освіта, в т. ч. безперервна, $\epsilon$ важливим інструментом забезпечення та піАтримання високої професійної майстерності. 3 огляду на це Аля піАготовки кваліфікованих бухгалтерів, що можуть виходити за межі загальновизнаної облікової методології та доповнювати ї якісно новими методами збору й обробки інформації, їх навчання в системі вищої та безперервної освіти повинне грунтуватися на новітніх навчальних технологіях і готувати сучасного фахівця Аля роботи 3 Ааними різного типу та якості, зАатного зАійснювати конверсію одного їх виду в інший із урахуванням запитів користувачів.

3 метою забезпечення умов всеохоплюючої й справеАливої якісної освіти та заохочення можливості безперервного навчання впродовж життя в частині бухгалтерської підготовки у вітчизняній системі освіти основну увагу потрібно приАімяти впровадженню таких новацій, як:

- поліпшення якості надання освітніх послуг через піАвищення професійної майстерності викмадачів, широке залучення Ао процесу навчання викмадачів-практиків; 
- оновлення навчальних технологій і зміна співвіАношення теорії та практики при піАготовці облікових фахівців, зміщення фокусу в навчальному процесі на тренінгові метоАи, інтерактивні вправи, роботу наА кейсами, Аискусійні завдання й проекти, роботу в махих групах, групові Аіалоги тощо;

- перехіА на широке застосування інформаційно-компютерних техномогій Аля виконання навчальних завдань (ведення обліку, скмадання й поАання звітності різних типів, провеАення анацізу звітних показників, формування аудиторських вибірок та використання аудиторських процеАур, створення робочих Аокументів аудитора тощо);

- зміна типу віАносин між викмадачем і студентом із авторитарного (виклаАач встанов ює правима взаємодії) на тьюторський (студент встанов ює правима взаємодії). Це передбачає піАвищення професійної обізнаності стуАентів, що Аає їм можмивість обирати ефективніші навчальні моделі;

- розвиток освіти Аля Аорослих упродовж усього життя на базі вітчизняних закмадів освіти, а також підтримка безперервної професійної освіти в системі 3ВО;

- створення відкритих баз знань Аля забезпечення можливості самостійної освіти та отримання базових спеціальних знань, удосконалення вже набутих знань і вмінь, підвищення професійної кваціфікації протягом цілого життя.

ЗавАяки таким новаціям система базової професійної піАготовки бухгалтерів перетвориться на безперервний процес навчання впродовж життя. При цьому досягнення глоба ьної цілі “Якісна освіта" відіграє важливу роль

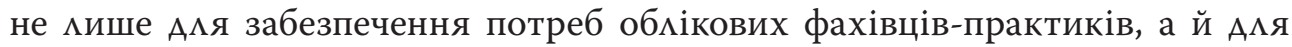
піАвищення ефективності функціонування українських 3ВО.

Аосягнення ще оАнієї, виокремленої Аля цього досліАження, глобальної цілі "Гендерна рівність" може віАбуватися в різних сферах суспі ььного життя - економічній, соціацьній, політичній. При цьому Аійсне забезпечення гендерної рівності сереА працівників організацій і піАприємницьких структур, розширення прав та можмивостей жінок можна побачити за віАповіАними якісними показниками публічної інформації. САіА зауважити, що бухгалтерська професія в Україні “має жіноче обличчя”, в піАрозАілах бухгалтерії, фінансових і аудиторських департаментах, у податкових службах працюють переважно жінки, які в більшості випаАків їх очолюють. Отже, в бухгалтерській (фінансовій) професії глобальна ціль гендерної рівності виконується Аосить успішно.

На підставі викцаденого доходимо таких висновків. Розглянуті процеси, пов'язані з реалізацією глобацьної концепції сталого розвитку, свіАчать: сучасний бізнес-світ вимагає віА компаній і організацій карАинамьного перегляду системи інформаційного забезпечення управління та трансформації їі віАповіАно до змінюваних інформаційних потреб користувачів.

ГАобальні цілі сталого розвитку та особливості їх реалізації в бухгалтерській професії підтверджують наявність низки невирішених питань і суперечностей у підходах та баченні глобальних і міжнародних організацій у частині піАготовки звітної інформації з розкриттям показників сталості А^я 
цілей стейкхолдерів. КАючовими напрямами новацій, які забезпечать піАготовку звітності нових форматів, доцікьно визначити:

- запровадження в організаціях принципів сталого розвитку, що сприяють Аосягненню Аовгострокової економічної ефективності, створенню користі Аля суспі ьства; перегляА менеАжментом компаній ролі бухгалтерів (управлінських бухгалтерів) в управлінських процесах, розширення їхньої участі в інформаційній піАтримці прийняття рішень із урахуванням піАготовки нових форматів звітності;

- формування в організаціях спеціалізованих підрозділів на базі бухгалтерської служби Аля піАготовки звітності нових форматів (Аепартаментів стратегічного обліку, звітності компанії, сталого розвитку бізнесу);

- розроблення сучасної методологічної бази Аля забезпечення функціонування підсистеми стратегічного управАінського обАіку, в котрій готуються нові формати звітності;

- узгодження форматів нефінансової й інтегрованої звітності Аля цілей сталого розвитку;

- створення системи незалежного аудиторського контролю Аостовірності нефінансових та інтегрованих звітів;

- навчання й піАвищення кваліфікації бухгалтерів (управлінських бухгалтерів, фінансових фахівців) Аля опрацювання нефінансових Ааних математичними, статистичними, анаАітичними метоАами;

- розвиток освіти Аля Аорослих упродовж усього життя, безперервної професійної освіти на базі вітчизняних заклаАів освіти, зокрема Аля бухгалтерівпрактиків, створення віАкритих баз знань Аля забезпечення можАивості самостійної освіти, вАосконахення вже набутих знань і вмінь, піАвищення професійної кваліфікації бухгалтерів, зАобуття освіти протягом цілого життя.

Насамкінець сліА згадати про глобальну ціль "Партнерство заради стамого розвитку", яка переАбачає сприяння розбудові миролюбного й всеохопмюючого суспільства, забезпечення кожному Аоступу Ао правосудАя та створення ефективних, піАзвітних, інкАюзивних інституцій на всіх рівнях, а також забезпечення рівноправного Аоступу до інформації й знань. Саме в реалізації цієї глобальної цілі професійні та високоосвічені бухгалтери повинні віАіграти у XXI ст. оАну з кмючових ролей.

\section{Список використаних Ажерем}

1. Цели развития тысячелетия: доклаА за 2015 год / ООН. Нью Йорк, 2015. 75 с.

2. Transforming our world: the 2030 Agenda for Sustainable Development : Resolution adopted by the General Assembly on 25 September 2015. 35 p.

3. GRI Sustainability Reporting Standards / GRI Standards Download Center ; Global Reporting Initiative. URL: https://www.globalreporting.org/standards/gri-standardsdownload-center/.

4. The Road Ahead. The KPMG Survey of Corporate Responsibility Reporting 2017 / KPMG. 2017. 56 p.

5. Baue B. Sustainability reporting: does G4 enhance sight but obscure vision? The Guardian. 2013. May 24. URL: https://www.theguardian.com/sustainable-business/sustai nability-reporting-g4-sight-vision. 
6. McElroy M. Has the GRI consigned itself to irrelevance? GreenBiz. 2013. May 22. URL: https://www.greenbiz.com/blog/2013/05/22/has-gri-consigned-itself-irrelevance.

7. Directive 2013/34/EU of the European Parliament and of the Council of 26 June 2013 on the annual financial statements, consolidated financial statements and related reports of certain types of undertakings, amending Directive 2006/43/EC of the European Parliament and of the Council and repealing Council Directives 78/660/EEC and 83/349/EEC. URL: https://eur-lex.europa.eu/legal-content/EN/ALL/?uri=CELEX\%3A32013L0034.

8. Зубілевич C. Облікова Аиректива $Є С$, iї вплив на склад і зміст звітів європейських компаній та перспективи Аля України. Бухгалтерський облік і аудит. 2014. № 7. С. 3-15.

9. Озеран А. Аиректива 2013/34/ЄС щодо річної фінансової звітності: Аискусійні питання та напрями їі імплементації в нормативну базу України. Бухгалтерський облік i aydum. 2015. № 5. C. 2-10.

10. The International Integrated Reporting Council (IIRC). URL: http://integrated reporting.org/the-iirc-2/.

11. The International $<\mathrm{IR}>$ Framework / The International Integrated Reporting Council ('the IIRC'). 2013, Dec. 35 p. URL: http://integratedreporting.org/resource/internationalir-framework/.

12. Adams C. A. The Sustainable Development Goals, integrated thinking and the integrated report / The International Integrated Reporting Council (IIRC). 2017, Sept. 51 p.

13. Corporate Register. URL: http://corporateregister.com/.

14. Corporate Register. Tools. Live Charts. URL: http://www.corporateregister.com/ livecharts $/$ ?chart $=1 \& \mathrm{cou}=\mathrm{All} \& \mathrm{sec}=\mathrm{All} \& \mathrm{sub}=\mathrm{All} \&$ our $=$ All .

15. GRI's Sustainability Disclosure Database. URL: http://database.globalreporting.org/.

16. Examples Database of the International Integrated Reporting Council (IIRC) and Black Sun Plc. URL: http://examples.integratedreporting.org/leading_practices.

17. Райан Б. Стратегический учет Аля руководителя / пер. с англ. ; под реА. В. А. Микрюкова. М., 1998. 616 с.

18. Уорд К. Стратегический управленческий учет / пер. с англ. М. : Олимп-Бизнес, 2002. 448 c.

19. Управленческий учет / А. Э. Аткинсон, Р. А. Банкер, Р. С. Каплан, М. С. Янг ; пер. с англ. 3-е изА. М. : Вимьямс, 2007. 880 с.

20. Мошковська О. А. Концептуацьні засади стратегічного управцінського обціку. Актуальні проблеми економіки. 2012. № 12. С. 151-159.

21. Глобальні принципи управлінського обліку / Привікейований інститут управлінських бухгалтерів (Chartered Institute of Management Accountants (CIMA)). 2014. 56 с.

22. Changing Competencies and Mindsets. Creating a vision for the future research emerging themes / Chartered Global Management Accountant; Association of International Certified Professional Accountants. 2018. 9 p.

23. The Changing Shape of the Finance Function. Creating a vision for the future research emerging themes / Chartered Global Management Accountant ; Association of International Certified Professional Accountants. 2018. 11 p.

24. Purpose Beyond Profit. The Value of Value - Board-level Insights / Black Sun PLC ; Association of International Certified Professional Accountants. 2018. 26 p.

\section{References}

1. United Nations. (2015). The Millennium Development Goals Report 2015. New York [in Russian].

2. United Nations. (2015, September 25). Transforming our world: the 2030 Agenda for Sustainable Development. Division for Sustainable Development Goals.

3. GRI Standards Download Center. (n. d.). GRI Sustainability Reporting Standards. Retrieved from https://www.globalreporting.org/standards/gri-standards-download-center/.

4. KPMG. (2017). The Road Ahead. The KPMG Survey of Corporate Responsibility Reporting 2017. 
5. Baue, B. (2013, May 24). Sustainability reporting: does G4 enhance sight but obscure vision? The Guardian. Retrieved from https://www.theguardian.com/sustainable-business/ sustainability-reporting-g4-sight-vision.

6. McElroy, M. (2013, May 22). Has the GRI consigned itself to irrelevance? GreenBiz. Retrieved from https://www.greenbiz.com/blog/2013/05/22/has-gri-consigned-itself-irrelevance.

7. European Union. (2013). Directive 2013/34/EU of the European Parliament and of the Council of 26 June 2013 on the annual financial statements, consolidated financial statements and related reports of certain types of undertakings, amending Directive 2006/43/EC of the European Parliament and of the Council and repealing Council Directives 78/660/EEC and 83/349/EEC. Retrieved from https://eur-lex.europa.eu/legal-content/EN/ALL/?uri= CELEX\%3A32013L0034.

8. Zubilevych, S. (2014). EU accounting directive, its impact on the composition and content of reports of European companies and prospects for Ukraine. Accounting and auditing, 7, 3-15 [in Ukrainian].

9. Ozeran, A. (2015). Directive 2013/34/EU on the annual financial statements: discussion issues and directions for its implementation in the normative base of Ukraine. Accounting and auditing, 5, 2-10 [in Ukrainian].

10. The International Integrated Reporting Council (IIRC). (n. d.). Retrieved from http:// integratedreporting.org/the-iirc-2/.

11. The International Integrated Reporting Council. (2013, December). The International $<I R>$ Framework. Retrieved from http://integratedreporting.org/resource/international-irframework/.

12. Adams, C. A. (2017, September). The Sustainable Development Goals, integrated thinking and the integrated report. The International Integrated Reporting Council (IIRC).

13. Corporate Register. (n. d.). Retrieved from http://corporateregister.com/.

14. Corporate Register. (n. d.). Tools. Live Charts. Retrieved from http://www.corporateregister.com/livecharts $/$ ?chart=1\&cou=All\&sec=All\&sub=All\&our=All.

15. GRI. (n. d.). Sustainability Disclosure Database. Retrieved from http://database.globalreporting.org/.

16. International Integrated Reporting Council (IIRC), Black Sun Plc. (n. d.). Examples Database. Retrieved from http://examples.integratedreporting.org/leading_practices.

17. Ryan, B. (1998). Strategic Accounting for Management. Moscow [in Russian].

18. Ward, K. (2002). Strategic Management Accounting. Moscow: Olimp-Biznes [in Russian].

19. Atkinson, A. A., Banker, R. D., Kaplan, R. S., \& Young, M. S. (2007). Management Accounting. Moscow: Viliams [in Russian].

20. Moshkovska, O. A. (2012). Conceptual grounds for strategical managerial accounting. Actual problems of economics, 12, 151-159 [in Ukrainian].

21. Chartered Institute of Management Accountants. (2014). Global principles of management accounting [in Ukrainian].

22. Chartered Global Management Accountant, Association of International Certified Professional Accountants. (2018). Changing Competencies and Mindsets. Creating a vision for the future research emerging themes.

23. Chartered Global Management Accountant, Association of International Certified Professional Accountants. (2018). The Changing Shape of the Finance Function. Creating a vision for the future research emerging themes.

24. Black Sun PLC, Association of International Certified Professional Accountants. (2018). Purpose beyond Profit. The Value of Value - Board-level Insights. 